Research Article

\title{
Sequence variation in the melanocortin-1 receptor $(M C 1 R)$ pigmentation gene and its role in the cryptic coloration of two South American sand lizards
}

\author{
Josmael Corso, Gislene L. Gonçalves and Thales R.O. de Freitas \\ Programa de Pós-Graduação em Genética e Biologia Molecular, Departamento de Genética, \\ Universidade Federal do Rio Grande do Sul, Porto Alegre, Rio Grande do Sul, Brazil.
}

\begin{abstract}
In reptiles, dorsal body darkness often varies with substrate color or temperature environment, and is generally presumed to be an adaptation for crypsis or thermoregulation. However, the genetic basis of pigmentation is poorly known in this group. In this study we analyzed the coding region of the melanocortin-1-receptor $(M C 1 R)$ gene, and therefore its role underlying the dorsal color variation in two sympatric species of sand lizards (Liolaemus) that inhabit the southeastern coast of South America: L. occipitalis and L. arambarensis. The first is light-colored and occupies aeolic pale sand dunes, while the second is brownish and lives in a darker sandy habitat. We sequenced 630 base pairs of $M C 1 R$ in both species. In total, 12 nucleotide polymorphisms were observed, and four amino acid replacement sites, but none of them could be associated with a color pattern. Comparative analysis indicated that these taxa are monomorphic for amino acid sites that were previously identified as functionally important in other reptiles. Thus, our results indicate that $M C 1 R$ is not involved in the pigmentation pattern observed in Liolaemus lizards. Therefore, structural differences in other genes, such as $A S I P$, or variation in regulatory regions of $M C 1 R$ may be responsible for this variation. Alternatively, the phenotypic differences observed might be a consequence of non-genetic factors, such as thermoregulatory mechanisms.
\end{abstract}

Key words: adaptation, body color, crypsis, Liolaemidae, pigmentation genes.

Received: July 29, 2011; Accepted: December 2, 2011.

\section{Introduction}

Color pattern in animals has long attracted the attention of evolutionary biologists. Major questions on the mechanisms that generate such patterns depend on knowledge of the genetic basis underlying this trait, i.e., the connection between genotype and phenotype. The pigmentation system is also affected by selective forces such as crypsis, aposematism, thermoregulation and sexual signaling, which drive its variation (Hoekstra, 2006).

Most studies on animal pigmentation have focused on the melanin system, in which specialized cells (melanocytes) produce either black/brown (eumelanin) or yellow/ red (pheomelanin), primarily regulated by the melanocortin-1 receptor (MC1R) (Skoglund and Höglund, 2010).

With some exceptions, melanism involves the MC1R gene, which encodes the melanocortin-1 receptor (Mundy, 2005; Vidal et al., 2010). Not surprisingly, several amino acid substitutions have been associated with pigmentation phenotypes (either dark or light) in a large number of verte-

Send correspondence to Josmael Corso. Programa de Pós-Graduação em Genética e Biologia Molecular, Departamento de Genética, Universidade Federal do Rio Grande do Sul, Av. Bento Gonçalves 9500, Prédio 43.323, 91501-970 Porto Alegre, RS, Brazil. E-mail: josmaelcorso@gmail.com. brate species, including birds (Theron et al., 2001; Ling et al., 2003; Doucet et al., 2004; Mundy et al., 2004; Mundy, 2005; Baião et al., 2007; Uy et al., 2009, Vidal et al., 2010), reptiles (Rosenblum et al., 2004, 2010) and mammals (Kijas et al., 1998; Vage et al., 1999; Ritland et al., 2001; Eizirik et al., 2003; Hoekstra and Nachman 2003; Mundy and Kelly, 2003; Nachman et al., 2003; Hoekstra et al., 2006; McRobie et al., 2009). However, in other cases $M C 1 R$ does not seem to be involved in color differences, for example, amphibians (Herczeg et al., 2010), reptiles (Rosenblum et al., 2004), birds (MacDougall-Shackleton et al., 2003; Cheviron et al., 2006) and mammals (Mundy and Kelly, 2003; Hosoda et al., 2005; Wlasiuk and Nachman, 2007; Loehr et al., 2008; Anderson et al., 2009; Ayoub et al., 2009; Gonçalves et al., 2012). This suggests that other candidate loci are responsible for the coloration, such as the $M C 1 R$ antagonist Agouti signaling protein (ASIP). In reptiles, melanophores produce mainly eumelanin, and the concentration of granules within these cells determines the overall coloration (Rosenblum et al., 2004). In general, specimens appear lighter when pigment is concentrated, and darker when it is dispersed through the cells. Thus, the $M C 1 R$ activity might affect only the amount of melanin produced. Accordingly, changes in the production and dispersion of melanin granules are ultimately responsible for 
changes in the dorsal color (Rosenblum et al., 2004). Dorsal body darkness in reptiles often varies with the substrate color or temperature of the environment, and is generally presumed to be an adaptation for crypsis or thermoregulation (Kettlewell, 1973). Coloration affects visibility to avian predators, so natural selection for substrate matching is predicted to be strong for diurnal reptiles (Norris, 1965). Pigmentation also impacts thermoregulation because darker reptiles are able to warm faster and maintain higher body temperatures (e.g., Bittner et al., 2002). Geographical variation in dorsal color is frequent in reptiles (Majerus, 1998) and selective pressures may be involved (Robertson and Rosenblum, 2009).

Liolaemus is placed in a broadly diverse family of lizards (Liolaemidae) and includes more than 200 species (Etheridge, 2000). In general, members of this genus occur in several habitats, particularly extensive areas of sand dunes, including the coasts of Chile, Argentina, Uruguay, and southeastern Brazil (Silva and Verrastro, 2007). Additionally, they occupy inland dune systems scattered throughout Argentina and Chile. The genus is characterized by striking ecological versatility, with often conspicuous cryptic color patterns (Etheridge, 2000; Silva and Verrastro, 2007). In this study we have focused on two species: Liolaemus occipitalis and L. arambarensis. The former is restricted to coastal sand dunes in the states of Santa Catarina (SC) and Rio Grande do Sul (RS) in southern Brazil. It has a cryptic light-colored pattern that exactly matches the pale background substrate (Bujes and Verrastro, 2006) (Figure 1A-B). Liolaemus arambarensis is endemic to a narrow area of inland dunes around Patos Lagoon in southern Brazil (Silva and Verrastro, 2007). Its pigmentation is brownish, and the habitat is also markedly darker; therefore this species also shows a cryptic color pattern (Verrastro et al., 2003; Bujes and Verrastro, 2006) (Fig 1C-D). These species are members of the wiegmannii group (Verrastro et al., 2003).

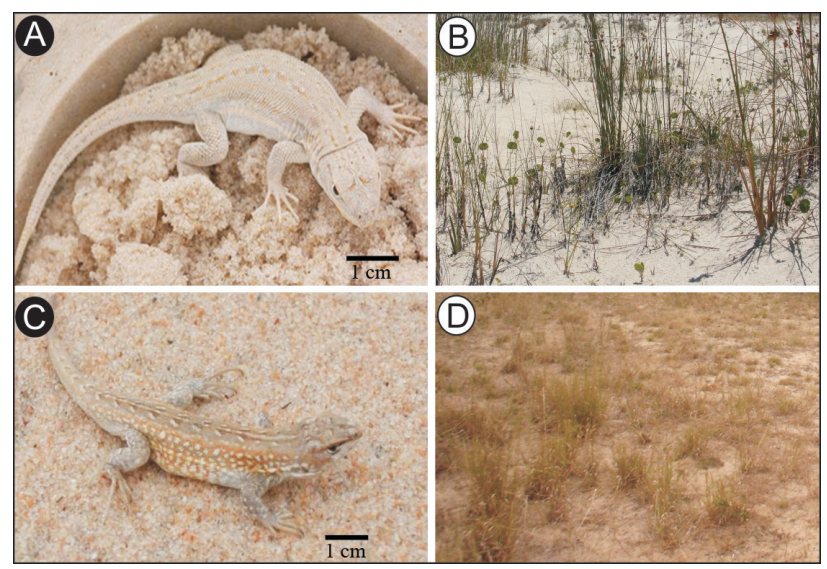

Figure 1 - South American sand lizards and their habitat. A, Liolaemus occipitalis (Photo: André Martins), B, pale coastal-dune substrate; C, L. arambarensis (Photo: Márcio Borges-Martins), D, darker inland sandy substrate.
In this study, we examined the $M C 1 R$ sequence variation in L. occipitalis and L. arambarensis lizards. Our main question was whether the light and dark phenotypes of these species are caused by changes in the MC1R coding region. Additionally, we addressed whether similar sequence variations are responsible for population differences in color.

\section{Material and Methods}

A total of 77 samples were collected across the distributional range of both species; 50 individuals of $L$. occipitalis (Loc) and 27 of L. arambarensis (Lar) (Table 1). Primers were designed for the $M C 1 R$ coding region amplification based on the sequence of Phrynosoma platyrhinos (AY586114). Polymerase chain reaction (PCR) amplification was surveyed using the primer pair MC1R_F 220 5'-TACTACTTCATCTGCTGCCTGGC-3' and MC1R_R 870 5'-GCATAAATGATGGGGTCCAC-3', under the following conditions: initial denaturation at $94{ }^{\circ} \mathrm{C}$ for $3 \mathrm{~min}, 30 \mathrm{~s}$ at $94{ }^{\circ} \mathrm{C}, 45 \mathrm{~s}$ at $61.5^{\circ} \mathrm{C}$, and $60 \mathrm{~s}$ at $72{ }^{\circ} \mathrm{C}(30$ cycles), followed by a final 5 -min extension period at $72^{\circ} \mathrm{C}$. PCR products were sequenced directly with the amplification primers, using an $\mathrm{ABI} 3730$ automatic sequencer (Applied Biosystems). Putative heterozygous sites were identified by visual inspection of the chromatograms, and confirmed by sequencing the complementary strand. The sequences were deposited in GenBank under accession numbers JF825310-JF82538. Amino acid sequences were aligned and translated using BIOEDIT v. 7 (Hall, 1999).

Standard variation parameters such as number of variable sites and haplotypes, haplotype diversity and nucleotide diversity were calculated using DNASP v. 5 (Librado and Rozas, 2009). We tested for evidence of selection at $M C 1 R$ by calculating Tajima's $D$ statistic and Fu's neutrality test $\left(F_{\mathrm{S}}\right)$ using ARLEQUIN 3.1 (Excoffier et al., 2005). Intraspecific genealogy based on network inference of haplotypes were reconstructed by NETWORK 4.6 (Bandelt et al., 1999) using the median joining approach.

\section{Results}

A total of $630 \mathrm{bp}$ of the coding region of the $M C 1 R$ gene was investigated, which includes all previously known sites involved in color variation in other reptiles, and also most of those mutations identified in other vertebrates. Twelve nucleotide polymorphic sites were observed, which resulted in four amino acid changes (Table 1).

The substitution at amino acid site 88, from Glu $>$ Ala, occurred in 11 individuals of L. occipitalis (260, 261: Morro dos Conventos, Santa Catarina (SC); 275, 276, 277, 278, 279, 280: Rio Grande, Rio Grande do Sul (RS); and 211, 212, 214: Taim, RS) and three individuals of $L$. arambarensis (479, 481, 485: Arambaré, RS); this change is from a negative polar amino acid to a neutral nonpolar charged amino acid. Another substitution at site 93 from 


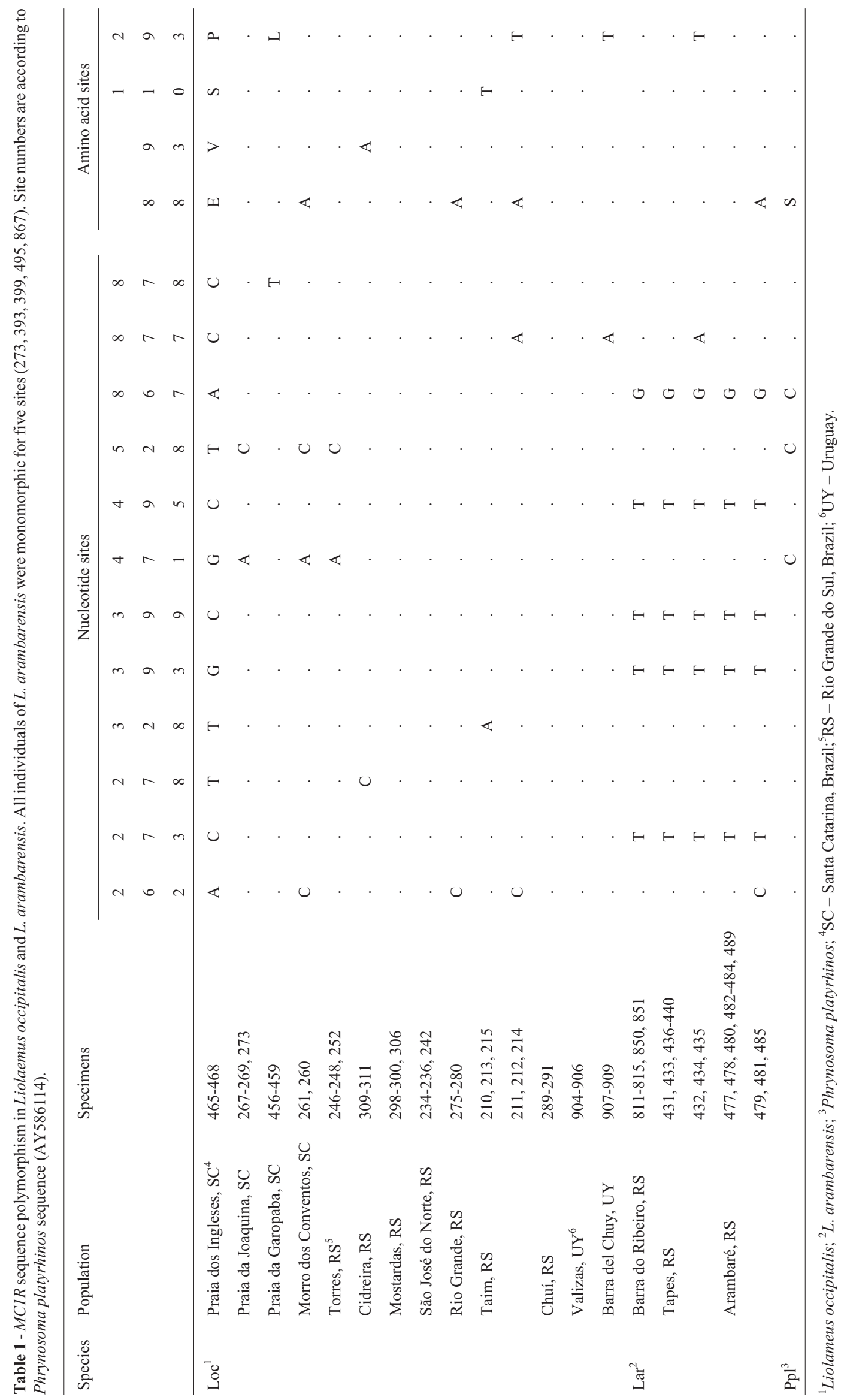


Val > Ala was found in only one locality of $L$. occipitalis (309, 310, 311: Cidreira, RS), both were an uncharged amino acid. In three individuals of $L$. occipitalis $(210,213$, 215: Taim, RS), at site 110 from Ser $>$ Thr both were neutral polar. At site 293 from Pro > Leu in individuals of $L$. occipitalis (456, 457, 458, 459: Praia da Garopaba, SC) was an uncharged amino acid. At site 293, another substitution occurred, from Pro $>$ Thr $(210,211,212,213,214,215$ : Taim, RS; 907, 908, 909: Barra del Chuy, Uruguay) and in three specimens of L. arambarensis $(432,434,435$ : Arambaré, RS), the change was from an uncharged amino acid to a neutral polar amino acid (Table 1).

Seven polymorphic sites were variable among the light haplotypes, whereas two sites were variable among the dark haplotypes (Table 1). The ratio of variant to invariant sites was significantly different between light and dark alleles (7/630 and 2/630, Fisher's exact test, $p<0.01)$. The mean level of nucleotide diversity among light alleles $(\pi=0.0025)$ was higher than the nucleotide diversity among dark alleles $(\pi=0.0006)$ (Table 2$)$. We did not observe any predicted protein sequence that was unique for each species. The Tajima's $D$ statistic, a measure of the relationship between the number of segregating sites and nucleotide diversity, indicated non-significant results $(D=0.981, \mathrm{p}>0.01)$ (Table 2). Fu's $F_{S}$ test of neutrality is a method to further evaluate the polymorphic patterns under population growth and genetic hitchhiking. The values were not statistically significant for these sand lizards $(\mathrm{p}>0.01)$, i.e., there was no deviation from neutrality (Table 2). In total, 12 haplotypes were observed: 9 in Liolaemus occipitalis (H1-H9; Table 1 and Figure 2) and 3 in L. arambarensis (H10-H12; Table 1 and Figure 2), none of them were shared between species. The H1 showed the highest frequency, and was distributed through the range of L. occipitalis (Figure 2A). In L. arambarensis the most frequent haplotype was H10, which was also present in all three populations of these species (Figure 2A). All other haplotypes showed low frequencies in both taxa.

\section{Discussion}

Contrary to expectations, a straightforward relationship between variation in $M C 1 R$ and color phenotypes could not be denoted in the two species of Liolaemus studied here. No common amino acid replacement was found exclusively in the dark-colored morph, although unique nucleotide polymorphisms were observed. Moreover, previously known amino acid replacements that are associated with dark-colored phenotypes in other lizard species were not identified in these species. For example, in the Eastern Fence Lizard (Sceloporus undulatus), Little Striped Whiptail (Aspidoscelis inornata) and Lesser Earless Lizard (Holbrookia maculata), single-point mutations for amino acids 168,170 and 208, respectively, are strongly associated with the degree of melanism (Rosenblum et al., 2004; 2010). Nevertheless, we did not detect any association between the amino acid variation at MC1R and the range of darkness in sand lizards.

The ratio of nonsynonymous and synonymous substitution $(d N / d S)$ is widely used to test the selective neutrality of protein coding genes. Most nonsynonymous substitutions are eliminated from populations by purifying selection (Nakayama et al., 2008). However, we did not observe any nonsynonymous substitutions associated with the differing color phenotypes in sand lizards in the sequence region of $M C 1 R$. Despite the high diversity of sites in $M C 1 R$ that are potentially associated with changes in color, there is no detectable pattern of which sites are responsible for changes, either among species of the same group or between groups of sand lizards in our analysis. Previous studies of reptiles have found species with polymorphism in coloration and association with the MC1R gene, and also species that did not show such an association (Rosenblum et al., 2004), as well as no detectable changes in the function of the receptor (Rosenblum et al., 2010). In species in which changes in the gene were associated with the light/dark color, a single site of the protein was found to be responsible. In other taxa such as birds and mammals (except for some cases in which the same site of the protein is responsible for light/dark alterations in different species), many substitutions are found in only one species, i.e., there is no consistent pattern of sites responsible for the formation of a particular phenotype (e.g., tuco-tucos; Gonçalves et al., 2012). The existence of different molecular bases for the same phenotype in two different taxa provides strong evidence for convergent phenotypic evolution on a relatively short time scale (Nachman et al., 2003). Different sites can be responsible for similar effects. However, previous studies that included 3D modeling have indicated certain regions of the protein as the most likely replacements,

Table 2 - Summary statistics of genetic variation and statistical tests of neutrality for phased sequence data of MC1R based on total dataset and Liolaemus occipitalis and $L$. arambarensis subpopulations: $\mathrm{N}$, number of specimens; $\mathrm{S}$, number of segregating sites; $\pi$, nucleotide diversity; $\mathrm{H}$, number of haplotypes; Hd, nucleotide diversity \pm standard error; $D$, Tajima's test of neutral model, and $F s$, Fu's $F s$ test of neutral model. $\mathrm{p}>0.01$.

\begin{tabular}{lccccccc}
\hline Species & $\mathrm{N}$ & $\mathrm{S}$ & $\Pi$ & $\mathrm{H}$ & $\mathrm{Hd}$ & D & FS \\
\hline L. occipitalis & 50 & 7 & 0.00250 & 9 & $0.813 \pm 0.04$ & 0.021 & -2.101 \\
L. arambarensis & 27 & 2 & 0.00065 & 3 & $0.384 \pm 0.10$ & -0.443 & -0.384 \\
MC1R total & 77 & 12 & 0.00557 & 12 & $0.848 \pm 0.02$ & 0.981 & -0.679 \\
\hline
\end{tabular}




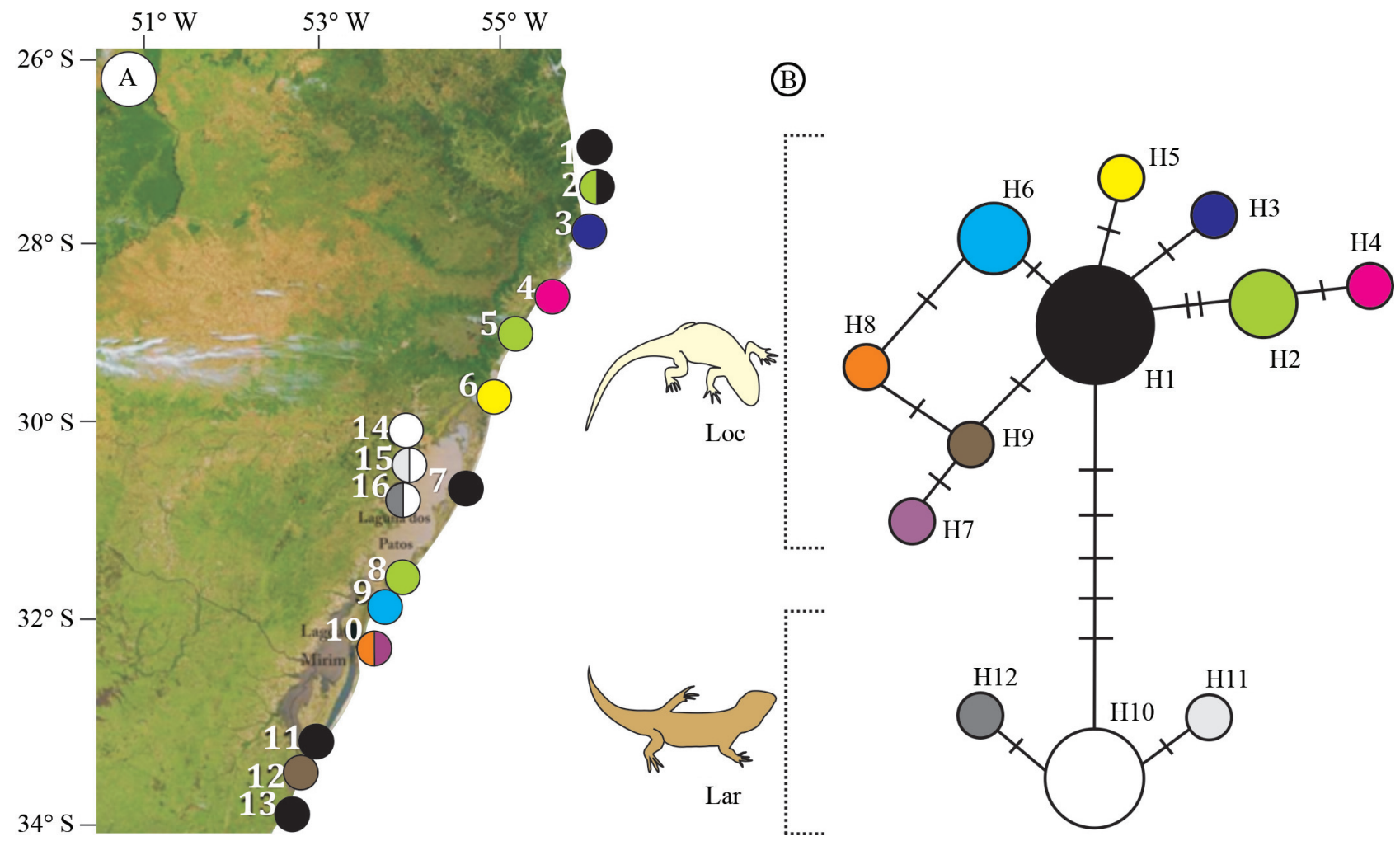

Figure 2 - $M C 1 R$ haplotypes based on 630 bp of $M C 1 R$ sequences. A, Populations sampled in this study and haplotypes observed. Numbers identify each locality: 1- Praia dos Ingleses, SC; 2- Praia da Joaquina, SC; 3- Garopaba, SC; 4- Morro dos Conventos, SC; 5- Torres, RS; 6- Cidreira, RS; 7- Mostardas, RS; 8- São José do Norte, RS; 9- Rio Grande, RS;10- Taim, RS; 11- Chuí, RS; 12- Barra del Chuy, UY; 13- Valizas, UY; 14- Barra do Ribeiro, RS; 15Tapes, RS; 16- Arambaré, RS. B, network constructed based on median-joining approach for 12 haplotypes found in L. occipitalis (Loc) and $L$. arambarensis (Lar). Circle areas are proportional to sample sizes. Each line segment represents a single substitution.

such as the region of the second and third transmembrane domain or the second and third extracellular loop on the MC1R (McRobie et al., 2009).

Whereas for some reptiles gene activity is altered by the influence of the mutation in the MC1R gene, in others such as sand lizards, different genetic variations may influence the phenotype, e.g., at downstream regulatory regions of the MC1R. The results of this study encourage further analysis of the $M C 1 R$ and the factors that regulate the expression of the gene.

Our study did not include analysis of noncoding regions (promoter region and 3' untranslated region) of the $M C 1 R$ gene. Recently, mutations in regulatory regions have been proposed as a fine-tuning mechanism, because mutations in specic cis-regulatory elements may alter the expression of a protein in particular tissues, while preserving expression in others (Hoekstra, 2006; Nakayama et al., 2008). However, all known mutations in the MC1R gene, many of which are adaptive, occur in the coding region, either as amino acid changes or as small deletions (reviewed by Hoekstra, 2006; Majerus and Mundy, 2003). Thus, the investigation of the noncoding region of MC1R and the other genes associated with pigmentation may be another way to understand the development of light/dark color in reptiles, and should be further analyzed in Liolaemus lizards.

In reptiles, the development of light/dark phenotypes might be a result of adaptation to different environments (Rosenblum, 2005). Melanism has evolved repeatedly in vertebrates, likely driven by both natural and sexual selection, so at the polymorphism level, the MC1R shows nonneutral evolution (Hoekstra, 2006; Nakayama et al., 2008). First, consider that melanism is the occurrence of individuals that are darker in pigmentation, either as polymorphisms within species or as consistent variation between closely related species (True 2003), in which sexual selection is the most likely (Clusella-Trullas et al., 2008). Moreover, in general, melanistic diurnal species inhabit cooler areas than do lighter-colored ones, where an adaptation to cold climates could be involved. In addition, a trade-off between melanism and body size has been suggested, as well as a co-evolution of color, behavior and physiology (Clusella-Trullas et al., 2008). Although the thermal-melanism hypothesis seems plausible, only a few investigators have provided data supporting data (Clusella-Trullas et al., 2008). Hence, we suggest that their habitats may possibly influence the species of Liolaemus studied here, with wider seasonal temperature variations in the continental than in coastal areas. Liolaemus arambarensis, which lives in in- 
land regions, might have developed a greater degree of melanization as a thermal-adjustment mechanism. On the other hand, L. occipitalis, which occurs in the coastal dunes, i.e., near the ocean and with narrower temperature ranges, has a lesser degree of melanization. It is known that temperature influences the melanocyte-stimulating hormone that affects melanin dispersion (Stuart-Fox and Moussalli, 2009). Other studies have shown how visual characteristics, such as shape, contrast, texture and edges of background objects influence the type of camouflage pattern adopted by a species (Zylinski et al., 2009; Stuart-Fox and Moussalli, 2009).

In summary, we ruled out the existence of mutations in the $M C 1 R$ gene that can be directly linked to the phenotypes observed in Liolaemus. In other words, there is no single pattern of change in MC1R that is responsible for variation in the light and brownish phenotypes of the lizard species studied.

Furthermore, a vast range of possibilities may lead to variation in color, illustrating the complex interaction of factors and mechanisms that may be involved in pigmentation phenotypes in reptiles. This complexity highlights the necessity to search for other processes underlying color variation in Liolaemus lizards.

\section{Acknowledgments}

We are grateful to Laura Verrastro (UFRGS) for providing tissue samples of Liolaemus, and to Caroline M. Silva (UFRGS) for helping in the field and making critical suggestions on the manuscript. We are also thankful to Janet W. Reid for editing the text. This study was supported by the Conselho Nacional de Desenvolvimento Científico e Tecnológico (CNPq) and the Coordenação de Aperfeiçoamento de Pessoal de Nivel Superior (CAPES). J. Corso and G.L. Gonçalves received CAPES and CNPq fellowships, respectively.

\section{References}

Anderson TM, von Holdt BM, Candille SI, Musiani M, Greco C, Stahler DR, Smith DW, Padhukasahasram B, Randi E, Leonard JA, et al. (2009) Molecular and evolutionary history of melanism in North American Gray Wolves. Science 323:1339-1343.

Ayoub NA, McGowen MR, Clark C, Springer MS and Gatesy J (2009) Evolution and phylogenetic utility of the melanocortin-1 receptor gene (MC1R) in Cetartiodactyla. Mol Phyl Evol 52:550-557.

Baião PC, Schreiber EA and Parker PG (2007) The genetic basis of the plumage polymorphism in red-footed booby (Sula sula): A Melanocortin-1 Receptor (MC1R) analysis. J Hered 98:287-292.

Bandelt H-J, Forster P and Röhl A (1999) Median-joining networks for inferring intraspecific phylogenies. Mol Biol Evol $16: 37-48$
Bittner TD, King RB and Kerfin JM (2002) Effects of body size and melanism on the thermal biology of garter snakes (Thamnophis sirtalis). Copeia 2002:477-482.

Bujes SC and Verrastro L (2006) Thermal biology of Liolaemus occipitalis (Squamata, Tropiduridae) in the coastal sand dunes of Rio Grande do Sul, Brazil. Braz J Biol 66:945-954.

Cheviron ZA, Hackett SJ and Brumfield RT (2006) Sequence variation in the coding region of the melanocortin-1 receptor gene (MC1R) is not associated with plumage polymorphism in the Blue-crowned Manakin (Lepidothrix coronata). Proc R Soc Lond B 273:1613-1618.

Clusella-Trullas S, Terblanche JS, Blackburn TM and Chown SL (2008) Testing the thermal melanism hypothesis: A macrophysiological approach. Funct Ecol 22:232-238.

Doucet SM, Shawkey MD, Rathburn MK, Mays HL and Montgomerie R (2004) Concordant evolution of plumage colour, feather microstructure and a melanocortin receptor gene between mainland and island populations of a fairy-wren. Proc R Soc Lond B 271:1663-1670.

Eizirik E, Yuhki N, Johnson WE, Menotti-Raymond M, Hannah SS and O'Brien SJ (2003) Molecular genetics and evolution of melanism in the cat family. Curr Biol 13:448-453.

Etheridge R (2000) A review of lizards of the Liolaemus wiegmannii group (Squamata, Iguania, Tropiduridae), and a history of morphological change in the sand-dwelling species. Herpetol Monogr 14:293-352.

Excoffier L, Laval G and Schneider S (2005) Arlequin ver. 3.0: An integrated software package for population genetics data analysis. Evol Bioinform Online 1:47-50.

Gonçalves GL, Hoekstra HE and Freitas TRO (2012) Striking color variation in tuco-tucos: A role for the Melanocortin-1 receptor? Biol J Linn Soc (Epub).

Hall TA (1999) BioEdit: A user-friendly biological sequence alignment editor and analysis program for Windows 95/98/NT. Nucleic Acids Symp Ser 41:95-98.

Herczeg G, Matsuba C and Merila J (2010) Sequence variation in the melanocortin-1 receptor gene (Mc1r) is not associated with the level of dorsal melanism in a widespread anuran. Annals Zool Fennici 47:37-45.

Hoekstra HE (2006) Genetics, development and evolution of adaptive pigmentation in vertebrates. Heredity 97:222-234.

Hoekstra HE and Nachman MW (2003) Different genes underlie adaptive melanism in different populations of rock pocket mice. Mol Ecol 12:1185-1194.

Hoekstra HE, Hirschmann RJ, Bundey RA, Insel PA and Crossland JP (2006) A single amino acid mutation contributes to adaptive beach mouse color pattern. Science 313:101-104.

Hosoda T, Sato JJ, Shimada T, Campbell KL and Suzuki H (2005) Independent nonframeshift deletions in the MC1R gene are not associated with melanistic coat coloration in three mustelid lineages. J Hered 96:607-613.

Kettlewell B (1973) The Evolution of Melanism: The Study of a Recurring Necessity. Clarendon Press, Oxford, 442 pp.

Kijas JMH, Wales R, Tornsten A, Chardon P, Moller M and Andersson L (1998) Melanocortin receptor 1 (Mc1r) mutations and coat color in pigs. Genetics 150:1177-1185.

Librado P and Rozas R (2009) DnaSP ver. 5: A software for comprehensive analyses of DNA polymorphism data. Bioinformatics 25:1451-1452.

Ling MK, Lagerstrom MC, Fredriksson R, Okimoto R, Mundy NI, Takeuchi S and Schioth HB (2003) Association of 
feather colour with constitutively active melanocortin 1 receptors in chicken. Eur J Biochem 270:1441-1449.

Loehr J, Worley K, Moe J, Carey J and Coltman DW (2008) MC1R variants correlate with thinhorn sheep colour cline but not individual colour. Can J Zool. 86:147-150.

MacDougall-Shackleton EA, Blanchard L and Gibbs HL (2003) Unmelanized plumage patterns in Old World leaf warblers do not correspond to sequence variation at the melanocortin-1 receptor locus (MC1R). Mol Biol Evol 20:1675-1681.

Majerus MEN (1998) Melanism: Evolution in Action. Oxford University Press, Oxford, pp 364.

Majerus MN and Mundy NI (2003) Mammalian melanism: Natural selection in black and white. Trends Genet 19:585-588.

McRobie H, Thomas A and Kelly J (2009) The genetic basis of melanism in the Gray Squirrel (Sciurus carolinensis). J Hered 100:709-714.

Mundy NI (2005) A window on the genetics of evolution: MC1R and plumage colouration in birds. Proc R Soc B 272:16331640.

Mundy NI and Kelly J (2003) Evolution of a pigmentation gene, the melanocortin-1 receptor, in primates. Am J Phys Anthropol 121:67-80.

Mundy NI, Badcock NS, Hart T, Scribner K, Janssen K and Nadeau NJ (2004) Conserved genetic basis of a quantitative plumage trait involved in mate choice. Science 303:18701873.

Nachman MW, Hoekstra HE and D'Agostino SL (2003) The genetic basis of adaptive melanism in pocket mice. Proc Natl Acad Sci USA 100:5268-5273.

Nakayama K, Shotake T, Takeneka O and Ishida T (2008) Variation of the Melanocortin 1 Receptor gene in the macaques. Am J Primatol 70:778-785.

Norris KS (1965) Color adaptation in desert reptiles and its thermal relationships. In: Milstead WW (ed) Lizard Ecology: A Symposium. University of Missouri Press, Columbia, pp 162-226.

Ritland K, Newton C and Marshallet HD (2001) Inheritance and population structure of the white-phased 'Kermode' black bear. Curr Biol 11:1468-1472.

Robertson JM and Rosenblum EB (2009) Rapid divergence of social signal coloration across the White Sands ecotone for three lizard species under strong natural selection. Biol J Linn Soc 98:243-255.

Rosenblum EB, Hoekstra HE and Nachman MW (2004) Adaptive reptile color variation and the evolution of the MC1R gene. Evolution 58:1794-1808.
Rosenblum EB, Römpler H, Schöneberg T and Hoekstra HE (2010) Molecular and functional basis of phenotypic convergence in white lizards at White Sands. Proc Natl Acad Sci USA 107:2113-2117.

Silva CM and Verrastro L (2007) Descrição do esqueleto axial de Liolaemus arambarenis Verrastro, Veronese, Bujes \& Dias Filho (Iguania, Liolaemidae): Regiões pré-sacral e sacral. Rev Bras Zool 24:1-11.

Skoglund P and Höglund J (2010) Sequence polymorphism in candidate genes for differences in winter plumage between Scottish and Scandinavian Willow Grouse (Lagopus lagopus). PLoS One 5:e10334.

Stuart-Fox D and Moussalli A (2009) Camouflage, communication and thermoregulation: Lessons from colour changing organisms. Phil Trans R Soc B 364:463-470.

Theron E, Hawkins K, Bermingham E, Ricklefs RE and Mundy NI (2001) The molecular basis of an avian plumage polymorphism in the wild: A melanocortin-1-receptor point mutation is perfectly associated with the melanic plumage morph of the bananaquit, Coereba flaveola. Curr Biol 11:550-557.

True JR (2003) Insect melanism: The molecules matter. Trends Ecol Evol 18:640-647.

Uy JA, Moyle RG, Filardi CE and Cheviron ZA (2009) Difference in plumage color used in species recognition between incipient species is linked to a single amino acid substitution in the melanocortin-1 receptor. Am Nat 174:244-254.

Vage DI, Klungland H, Lu D and Cone RD (1999) Molecular and pharmacological characterization of dominant black coat color in sheep. Mamm Genome 10:39-43.

Verrastro L, Veronese L, Bujes C and Dias Filho MM (2003) A new species of Liolaemus from southern Brazil (Iguania, Tropiduridae). Herpetology 59:252-277.

Vidal O, Araguas RM, Fernández R, Heras S, Sanz N and Pla C (2010) Melanism in guinea fowl (Numida meleagris) is associated with a deletion of Phenylalanine-256 in the MC1R gene. Anim Genet 41:656-658.

Wlasiuk G and Nachman MW (2007) The genetics of adaptive coat color in gophers: Coding variation at Mc1r is not responsible for dorsal color differences. J Hered 98:567-574.

Zylinski S, Osorio D and Shohet AJ (2009) Perception of edges and visual texture in the camouage of the common cuttlesh Sepia ofcinalis. Phil Trans R Soc B 364:439-448.

\section{Associate Editor: Fabrício Rodrigues dos Santos}

License information: This is an open-access article distributed under the terms of the Creative Commons Attribution License, which permits unrestricted use, distribution, and reproduction in any medium, provided the original work is properly cited. 